\title{
Teaching of the Subject of Solids Through Problem-Based Learning Approach
}

\author{
Ramis Bayrak ${ }^{1, *} \&$ Ahmet Gürses ${ }^{2}$ \\ ${ }^{1}$ Erzurum Vocational College, Atatürk University, Erzurum, Turkey \\ ${ }^{2}$ Kazım Karabekir Education Faculty, Atatürk University, Erzurum, Turkey \\ *Correspondence: Erzurum Vocational College, Atatürk University, Erzurum, Turkey. E-mail: \\ rbayrak@atauni.edu.tr
}

Received: April 17, 2020

Accepted: May 25, $2020 \quad$ Online Published: June 16, 2020

doi:10.5430/wje.v10n3p47

URL: https://doi.org/10.5430/wje.v10n3p47

\begin{abstract}
The aim of the study is to investigate the attitudes of prospective science teachers towards the use of problem-based learning methods in the learning of concepts related to the subject of solids, and their opinions on its role in academic success, science process skills and the chemistry course.

The study group consists of 83 prospective teachers studying in the science education undergraduate program. The experimental group and control group were determined by random sampling method. The problem-based learning method was used in the experimental group and the traditional approach was used in the control group. The experiment was carried out in a period of 5 weeks. As data collection tools; "Solid Concept Achievement Test", "Science Process Skill Test" and "The Attitude Scale toward Chemistry" were used.

In the research, analysis of covariance (ANCOVA), independent t-test and statistical methods with descriptions were used. The results showed that problem-based learning is more effective than the traditional approach to understanding the concepts related to solids by prospective teachers. The differences in academic achievement between the experimental and control groups in this study were parallel with the other results reported in the literature. Also, in terms of prospective teachers' development of science process skills and attitudes towards chemistry, it was seen that there was a significant difference between the groups in favor of problem-based learning.
\end{abstract}

Keywords: problem-based learning, traditional approach, solids, prospective teachers

\section{Introduction}

Education is a process of progress that aims to improve a person's skills, increase the number of their interest areas and strengthen their character (Bonsting, 1992). In general, education is also a process that includes learning and teaching. In this process, learning is an extremely important element and is defined in different ways. When we become aware of information that we did not know or can do an activity that we could not do, it is learning. Learning, in general, is the change of thought, emotion, and behaviour in the individual that occurs as a result of the interaction with the environment. However, there are different opinions on how this change occurs (Özden, 2005).

Today, the traditional method is not effective enough in teaching concepts. Because it is not enough for the student to define and memorize the concepts in order to comprehend the concepts and the relations between them. By providing suitable environments, students should be enabled to work as scientists and create scientific information by discovering and discussing them (Bodner, 1986). Learning and teaching methods and principles, which are constantly researched and developed, bring many different thoughts into the educational system. Active and effective learning approaches, which have come to the fore especially in recent years, are accepted by everyone. One of the most important of these approaches is problem-based learning.

\subsection{Problem-Based Learning}

Problem-based learning entered the literature as a teaching approach in the 1960s after the research conducted at the Medical School at McMaster University. However, real progress was made in the 1980s. No element in the process of change in education has made its mark on today's practices as much as "Problem-Based Learning" (Barrows and 
Tambyln, 1980; Rhem, 1998; Dicle, 2001).

Problem-based learning is an approach that takes all problems to the center, from the instructional objectives to student behavior, from the methods and techniques to be used to the measurement and evaluation processes to be performed. Therefore, in such an approach, firstly the goals and behaviors should be determined. After this determination, the methods and techniques to be used in the problem-solving phase will need to be selected.

The use of problem situations plays an important role in the functioning of the problem-based learning process. These kinds of problems are different from typical end-of-subject problems and they are based on daily life events in order to draw the attention of the student (Weiss, 2003; Yeung et al., 2003).

Problem-based learning is a student-centered approach. Therefore, the most important task belongs to the student. Roles of teacher and student change in problem-based learning.

Problem-based learning provides students with a lot of skills, knowledge, and experience, especially when used in applied courses and issues that can be solved in multiple ways. By giving events and situations related to real-life examples, this approach provides students the ability to overcome problems they may encounter in the future (Ryan and Koschmann, 1994).

\subsection{Steps of Problem-Based Learning}

According to Stepien et al. (1993), the steps of problem-based learning are:

\section{1- Problem identification and introduction}

2- Research

\section{3- Synthesis and application}

4- Measurement and Evaluation

\subsection{Problem-Based Learning, Science Education and the Subject of Solids}

The objectives of science education include teaching the art of thinking, developing concepts in the mind through experience, examining the cause-effect relationship and teaching analysis methods (Tobin, 1986). One of the first subjects that should be learned especially in chemistry and physics courses is the issue of solids. The majority of the objects we see in our environment are solid. However, seeing the object is not enough for us to recognize it. In order to know the solids well, they should be understood on a microscopic scale, too.

Among the studies on chemistry education, the most emphasized or prevalent topic is the subject of learning chemistry subjects and what can be done to improve learning and to achieve permanent learning. In the studies conducted, it is seen that the necessity of students to learn chemistry conceptually has gained importance (Markow and Lonning, 1998; Harrison and Treagust, 2001). For this reason, "teaching of the subject of solids through a problem-based learning approach" has been determined as the research subject.

In a study conducted by Cancilla (2001) to determine whether there are any health hazards in analyzing the water of the river going through the city of Rowan through problem-based learning for the analytical chemistry course, it is stated that these activities provide students with useful experiences on environmental issues. Cancilla also reports that the students realized how important it was to take notes during laboratory classes, gained invaluable information regarding environmental chemistry during their research, and had the chance to apply the basic concepts in chemistry while solving the problem. In addition, the researcher states that he received feedback from many of his former students who got a start in the business life that said what they learned in those activities gained them significant advantages.

Ying (2003), in the research he conducted, taught the subjects of electrochemistry of the physicochemistry course through problem-based learning and, he stated his reason to choose this approach was that he believed this method would benefit the students in their futures in terms of self-learning, note-taking, literature review, experiment design, cooperation, and hypothesis constructing. For this purpose, the researcher determined the air pollution in major cities in China as a problem situation and asked the students to investigate the causes of air pollution and the physical and chemical properties of the air. Ying divided the studies into groups of curricular theoretical studies, extracurricular research activities, and laboratory applications. In the course, research and laboratory results related to the problem are discussed and new researches or laboratory applications are proposed in the light of the results. Consequently, it is reported that problem-based learning contributed many skills to students, such as awareness of the fields of use of electrochemistry concepts, teamwork, research, the ability to use chemical analysis methods, and learning by doing.

In an experimental study by Şenocak (2005), the effect of the problem-based learning approach on students' understanding of gas-related concepts and their attitudes towards chemistry was compared with the effect of the traditional method. The findings of the research show that there is a statistically significant difference between the 
students in the experimental group using problem-based learning and the students in the control group in terms of their level of understanding of gas-related concepts and their attitudes towards chemistry. The research also reports that students have a positive attitude towards problem-based learning and students improved in terms of certain skills such as self-confidence, self-learning and problem-solving.

\subsection{The Aim of the Study}

The aim of the study is to investigate the attitudes of prospective science teachers towards the use of the problem-based learning method in the learning of concepts related to the subject of solids and their opinions on its role in academic success, science process skills, and the chemistry course.

In order to achieve the aim of the study, answers to the following questions were sought:

1- Is there a significant difference between the experimental group with which the problem-based learning approach was used and the control group with which the traditional approach was used in terms of understanding the concepts related to solids?

2- Is there a significant difference between the experimental group with which the problem-based learning approach was used and the control group with which the traditional approach was used in terms of the development of science process skills?

3- Is there a significant difference between the experimental group with which the problem-based learning approach was used and the control group with which the traditional approach was used in terms of the attitudes of prospective teachers towards chemistry?

\section{Method}

\subsection{The Pattern of the Study}

In the study, in order to determine the effectiveness of two different teaching approaches (problem-based learning and traditional) in teaching the subject of solids, "non-equivalent control group design" was used (McMillan and Schumacher 2001; Kaptan, 1998; Karasar, 1998).

In order to reveal the level of knowledge of prospective teachers on concepts related to solids, determine their attitudes towards chemistry and analyze their science process skills, solid concept achievement test, attitude towards chemistry course scale, and science process skill test were performed as pretests with all participant prospective teachers before the experiment, and after the experiment, the tests were performed again as posttests.

\subsection{Study Groups}

The sample of the study consists of 83 third-year undergraduate science teaching students from two different classes lectured by the same professor. An experimental group and a control group were determined by the random sampling method from the respective classes.

\subsection{Data Collection Tools}

\subsubsection{Solid Concept Achievement Test}

The solid concept achievement test consists of a total of 21 multiple-choice questions. While some of the questions in the test are developed by researchers, some of them are developed by utilizing the literature.

All questions in the test are related to the subject of solids. Each of these questions aims to measure a single concept related to the subject, but there are also different types of questions that examine the same concept.

The solid concept achievement test was applied to a group of prospective teachers who had studied solids before, and the reliability coefficient of the test (Kuder-Richardson) was found to be 0.66 . In order to achieve the validity of the solid concept achievement test, the opinions of the instructor of the course and the experts on the subject were taken. Experts stated that the validity of the test was sufficient to measure the concepts of solids.

\subsubsection{The Attitude Scale toward Chemistry}

This scale was developed by Geban et al. (1994) in order to determine prospective teachers' attitudes towards chemistry. The scale consists of fifteen items with five Likert-type options (totally agree, agree, undecided, disagree, totally disagree). The reliability coefficient of the scale (Cronbach Alpha) was found to be 0.83 by Geban et al. (1994).

The scale was applied to all prospective teachers as pretest and posttest. 


\subsubsection{Science Process Skill Test}

This test, which was developed by Okey, Wise, and Burns, consists of exercises that require the use of certain important abilities to measure the science process skills. The test contains thirty-six items prepared to measure five different science process skills. These skills are defining variables, hypothesis construction and expression, operational definition, research design, and graphing and interpretation of data (Pınarbaş1, 2002).

Translation and adaptation of this test into Turkish was made by Geban et al. (1992) and its reliability coefficient was found to be 0.81 . The science process skill test was applied as pretest and posttest to prospective teachers in both experimental and control groups.

\subsection{Application}

This study was applied for fourteen class hours to a total of 83 prospective teachers who are third-year science teaching undergraduate students. The study investigated the effectiveness of two different teaching approaches in learning concepts related to solids. For this purpose, the experimental and control groups were formed, and the subject of solids was taught with problem-based learning in the experimental group and the traditional approach in the control group.

In order to determine whether there is a significant difference between the groups, at the beginning of the experiment, solid concept achievement test, attitude towards chemistry course scale, and science process skill test were applied to the experimental and control groups simultaneously. The experiment commenced in both groups upon the completion of the pretests. The experiment was carried out by the researcher in both groups in accordance with the curriculum and it covered three class hours per week.

Before the experiment, the prospective teachers in the experimental group were informed about the functioning of the problem-based learning approach and a sample application was made on a problem situation. In the control group consisting of a total of 41 prospective teachers, the subject of solids was studied for fourteen class hours, just as in the experimental group, and according to the traditional teaching approach in which the researcher was active and the prospective teachers were passive.

\subsection{Data Analysis}

The data obtained from the pretest were analyzed by using the independent t-test.

After the experiment, the analysis of covariance (ANCOVA) was made to compare the traditional approach and problem-based learning in terms of their effects on academic success. In this analysis, pretest scores of science process skills and solid concept achievement tests of prospective teachers, which are considered as common variables, were taken into consideration.

In addition, the effect of the method on prospective teachers' attitudes towards chemistry was analyzed by independent $\mathrm{t}$-test.

\section{Findings}

In the study, statistical analyses were performed by using the SPSS/PC (Statistical Package for Social Sciences for Personal Computers) package program.

Analysis of the data obtained from pretests showed no significant statistical difference among the mean scores of the solid concept achievement test $(\mathrm{t}(81)=0.747, \mathrm{p}>0.05)$, attitude scale towards chemistry $(\mathrm{t}(81)=-1.141 ; \mathrm{p}>0.05)$, and science process skill test $(\mathrm{t}(81)=0.187 ; \mathrm{p}>0.05)$ of experimental and control groups.

The test results of the hypotheses of the research are as follows:

In terms of the achievements of the experimental group, where the problem-based learning was used and the control group, where the traditional approach on concepts related to solids, in order to determine the statistical difference between the mean scores of the posttest, the preliminary information and science process skills (SPS) of the prospective teachers were measured and the analysis of covariance (ANCOVA) was made. The results of the analysis were presented in Table 1. 
Table 1. ANCOVA Analysis Results

\begin{tabular}{rccccc}
\hline Source & sum of squares & SD & mean square & F & Sig.(P) \\
\hline SPS & 0,161 & 1 & 0,161 & 0,032 & 0,858 \\
Pretest & 29,519 & 1 & 29,519 & 5,921 & $0,017^{*}$ \\
Posttest & 281,446 & 1 & 281,446 & 56,456 & $0,000^{*}$ \\
Error & 383,864 & 77 & 4,985 & & \\
Total & 14882,000 & 83 & & & \\
$\mathrm{p}<0,05$ & & & &
\end{tabular}

As seen in Table 1, in terms of solid concept achievement test, there is a statistically significant difference between the pretest mean scores of prospective teachers in the experimental group and the prospective teachers in the control group $(\mathrm{F}(1.81)=56.456 ; \mathrm{p}<0.05)$. Solid concept achievement test mean score of prospective teachers in the experimental group using the problem-based learning was higher than the mean score of prospective teachers in the control group using the traditional approach $\left(\bar{X}_{\mathrm{E}}=15.02 ; \bar{X}_{\mathrm{c}}=11.00\right)$. As can be seen in Table 1, the prospective teachers whose solid concept achievement pretest scores were high received high scores in the posttest, too. This result shows that pretest scores are a good predictor of prospective teachers' solid concept achievements.

Is there a significant difference between the experimental group with which the problem-based learning approach was used and the control group with which the traditional approach was used in terms of understanding the concepts related to solid objects?

Table 2. The Experimental and Control Groups' Correct Answer Rates in the Solid Concept Achievement Pretest and Posttest

\begin{tabular}{lllll}
\hline \multirow{2}{*}{ Questions } & \multicolumn{3}{c}{ Experimental Group } & Control Group \\
\cline { 2 - 5 } & Pretest (\%) & Posttest (\%) & Pretest (\%) & Posttest (\%) \\
\hline 1 & 57.0 & 64.0 & 49.0 & 63.0 \\
2 & 36.0 & 86.0 & 27.0 & 51.0 \\
3 & 62.0 & 93.0 & 54.0 & 76.0 \\
4 & 50.0 & 52.0 & 37.0 & 51.0 \\
5 & 40.0 & 76.0 & 51.0 & 63.0 \\
6 & 48.0 & 71.0 & 32.0 & 54.0 \\
7 & 36.0 & 57.0 & 24.0 & 34.0 \\
8 & 67.0 & 93.0 & 46.0 & 68.0 \\
9 & 48.0 & 88.0 & 49.0 & 71.0 \\
10 & 57.0 & 76.0 & 44.0 & 68.0 \\
11 & 43.0 & 88.0 & 37.0 & 56.0 \\
12 & 57.0 & 95.0 & 46.0 & 63.0 \\
13 & 43.0 & 71.0 & 29.0 & 46.0 \\
14 & 43.0 & 74.0 & 41.0 & 61.0 \\
15 & 36.0 & 67.0 & 37.0 & 46.0 \\
16 & 36.0 & 57.0 & 29.0 & 34.0 \\
17 & 33.0 & 66.0 & 20.0 & 34.0 \\
18 & 38.0 & 69.0 & 27.0 & 51.0 \\
19 & 33.0 & 74.0 & 34.0 & 39.0 \\
20 & 26.0 & 52.0 & 22.0 & 37.0 \\
21 & 45.0 & 79.0 & 32.0 & 51.0 \\
\hline
\end{tabular}

Graph 4.2 shows the final rates of correct answer both in the pretest and posttest acquired by the experimental group, which used the problem-based learning, and the control group, which used the traditional approach. These results suggest that there are differences between the two groups in terms of the correct answer rates in the solid concept achievement test, and the correct answer rates of the experimental group are higher.

The success rate in questions 4, 7, 16 and 20 was lower than in other questions. As can be seen in Table 2, in the posttest, prospective teachers' correct answer rates in questions other than these questions are above $60 \%$. When the correct answer rates of the control group prospective teachers are analyzed, the correct answer rates are above 50\%, 
except for questions $7,13,15,16,17,19$ and 20 . It is seen that the correct answer rates of questions $3,8,9$, and 10 of both groups is over $65 \%$.

In general, after the experiment, the mean correct answer rate of the solid concept achievement test was $74 \%$ in the experimental group using the problem-based learning, while it was 53\% in the control group using the traditional approach. This result shows that the concepts about solids are better comprehended by the prospective teachers in the experimental group compared to the prospective teachers in the control group.

Is there a significant difference between the experimental group with which the problem-based learning approach was used and the control group with which the traditional approach was used in terms of the development of science process skills?

An independent t-test was conducted in order to test the second hypothesis, which would reveal whether problem-based learning and the traditional approach would have a significant effect on the science process skills of prospective teachers. These test results reveal that there is a statistically significant difference between the experiment and control groups $(\mathrm{t}(81)=2.964 ; \mathrm{p}<0.05)$ and the mean score of the science process skill posttest of the experimental group ( $\left.\bar{X}_{E}=27.48\right)$ was higher than that of the control group $\left(\bar{X}_{C}=25.75\right)$. In other words, there was a significant difference between the approaches applied for the development of science process skills. According to this result, it can be said that problem-based learning is more effective than the traditional approach for the development of science process skills.

Is there a significant difference between the experimental group with which the problem-based learning approach was used and the control group with which the traditional approach was used in terms of the attitudes of prospective teachers towards chemistry?

An independent t-test was conducted in order to determine whether there is a statistically significant difference between problem-based learning and traditional approach in terms of prospective teachers' attitudes towards chemistry. According to these test results, there was a statistically significant difference between the two groups ( $\mathrm{t}$ $(81)=4.506 ; \mathrm{p}<0.05)$. As seen in Table 3 , the posttest mean score of attitude scale towards chemistry of the experimental group is higher than that of the control group. In other words, prospective teachers who work with problem-based learning have a better attitude towards chemistry than those who work with the traditional approach.

Table 3. The Attitude Scale Towards Chemistry Pretest-posttest Mean Scores

\begin{tabular}{cccc}
\hline Group & $\begin{array}{c}\text { Number of Prospective } \\
\text { Teachers }\end{array}$ & Pretest Mean Scores & Posttest Mean Scores \\
\hline Experimental & 42 & 53,26 & 62,95 \\
Control & 41 & 55,32 & 56,90 \\
\hline
\end{tabular}

It can be stated that in problem-based learning practices, prospective teachers have the opportunity and pleasure to learn by themselves by getting the opportunity to search and access the information they need, and this situation has caused a positive attitude change in the experimental group.

\section{Discussion, Conclusion and Suggestions}

In this section, some suggestions that may provide insight into any future study on this subject are made by commenting on and discussing the findings.

For the study, the solid concept achievement test, which was developed in order to determine the knowledge levels of prospective teachers regarding the concept of solids, was applied as a pretest to prospective teachers in both the experimental and control groups before the experiment. The analysis results obtained from the test showed that there was no statistically significant difference between the success mean scores of both groups. In order to determine whether the experimental and control group prospective teachers are homogeneous in terms of science process skills, at the beginning of the experiment, the science process skill test was applied to all prospective teachers in both groups. The t-test results $(\mathrm{t}(81)=0.187 ; \mathrm{p}>0.05)$ showed that there was no statistically significant difference between the groups in terms of science process skills. Again, in order to test whether there is any difference between the experimental and control groups in terms of attitude towards chemistry, attitude towards chemistry course scale was applied to both groups at the beginning of the experiment and the t-test results of the obtained data $(\mathrm{t}(81)=$ $1.141 ; \mathrm{p}>0.05)$ revealed that there was no statistically significant difference between the groups in terms of their attitudes towards chemistry. Thus, it can be said that before the experiment, both groups were at an equal level in 
terms of solid concept achievement, science process skills and attitudes towards chemistry.

After the experiment, in order to compare the experimental and control groups in terms of solid concept achievement, the solid concept achievement test was applied to both groups as a posttest. The analysis of covariance (ANCOVA) of the obtained data $(\mathrm{F}(1.81)=56.456 ; \mathrm{p}<0.05)$ show that in terms of the successful learning of concepts related to solids, there is a significant statistical difference between the prospective teachers in the experimental group, in which problem-based learning was used, and the prospective teachers in the control group, in which the traditional approach was used. It was found that the solid concept achievement test mean score of the experimental group was higher than the mean score than that of the control group $\left(\bar{X}_{E}=15.02 ; \bar{X}_{C}=11.00\right)$, and mean correct answer rates were calculated as $74 \%$ in the experimental group and $53 \%$ in the control group.

These results reveal that the problem-based learning approach is more successful than the traditional approach in the learning of concepts related to solids by prospective teachers. This result obtained from the study is in line with the results of other studies examining the effectiveness of problem-based learning (Walker, 2001; Selco et al., 2003; Ying, 2003).

It can be said that directing prospective teachers in the experimental group towards research, and their efforts to find make solution offers for the problem situations facilitated their learning of concepts related to solids. The difference in the levels of success between the groups can be explained with the fact that in the experimental group, prospective teachers actively participated in the process of learning, made researches, provided solution suggestions and presented their findings during problem-based learning activities while in the control group the prospective teachers were merely passive listeners of what the instructor presented. On the other hand, it can be thought that the association of the topics with daily life during the discussion of solution suggestions, and the presentation of the structures of the solids with 3D animations also facilitated the learning process. In addition, it can be said that prospective teachers working in cooperative groups in problem-based learning activities had a positive effect on learning. It is reported in many studies that working in collaborative groups increases academic success (Polanco et al., 2004; Akpınar and Ergin, 2005).

It is very difficult for students to understand concepts related to solids. The difficulty of understanding is due to the fact that the concepts in this subject are quite abstract. It is emphasized in several pieces of research that objectifying highly abstract concepts will make it easier for students to understand these concepts (Harrison and Treagust, 2001; Bodner, 2001; Gülçiçek and Güneş, 2004). Therefore, it can be thought that the association of concepts with everyday life makes it possible to analyze the differences between the scientific knowledge used in problem situations and the knowledge possessed by students, which is one of the primary reasons why the students in the experimental group are more successful than the students in the control group. There are studies conducted in the area of conceptual change in the literature stating that this situation positively affects conceptual learning (Canpolat, 2002; Pınarbaş1, 2002).

The literature reports that problem-based learning increases the students' levels of academic success and creativity by allowing students to be more active in the learning environment, improves problem-solving skills of the students and enables continuous and meaningful learning (Milner-Bolotin and Svinicki, 2000; Cancilla, 2001; Chang, 2001; Açıkyıldız, 2004).

As stated above, in this study, the success rate of the experimental group was $74 \%$ and the success rate of the control group was $53 \%$ at the end of the experiment. In other words, there is a difference of $21 \%$ between the success rates of the experimental group and the control group. In addition, the pretest and posttest success rates of the experimental group were calculated as $44 \%$ and $74 \%$, respectively. Compared to the values in the literature, it can be said that the success rates obtained in this study are quite high. Many studies suggest that there is not much difference between the experimental and control groups in terms of academic success (Sundblad et al., 2002; Miller, 2003; Svinicki, 2007). In this study, the big difference between the groups may be associated with the development of the ability of prospective teachers in the experimental group to visualize the three-dimensional structures of solids in their minds in parallel with the positive development in their science process skills, as well as their heightened interest in the topic. Accordingly, it can be said that problem-based learning is an effective and feasible alternative approach in teaching solids.

In order to determine the effect of the method on the science process skills of prospective teachers, science process skill test was performed by all prospective teachers in the experimental and control groups. The analysis results of this test showed that the mean posttest success rate of the experimental group was higher than that of the control group and the difference between the mean scores was statistically significant $(\mathrm{t}(81)=2.964 ; \mathrm{p}<0.05)$. It can be interpreted that problem-based learning, which is a student-centered approach that also regards the science process 
skills, contributes more to students in their development of science process skills than the traditional approach. There are works in the literature stating that problem-based learning improves science process skills, but in some cases, this learning method should be used for a long time in order for this to happen (Padilla and Okey, 1984; Geban, 1990).

In this study, the two approaches whose effects on the learning of concepts related to solids were examined have been also analyzed to determine whether they have any effects on the attitudes of prospective teachers towards chemistry by using the attitude towards chemistry course scale. The analysis of the data showed that there was a statistically significant difference between the experimental and control groups in terms of their attitudes towards chemistry $(\mathrm{t}(81)=4.506 ; \mathrm{p}<0.05)$. The mean score of the chemistry course attitude scale posttest was higher in the experimental group than the control group. This result shows that problem-based learning is more effective than the traditional approach in terms of developing a positive attitude towards chemistry course. The literature states that active learning approaches such as problem-based learning affect students' attitudes towards science lessons positively, increase their interest and curiosity towards science and as a result, their success increases (Freedman, 1997; Tepe, 1999).

In light of these results, the following suggestions can be made;

If the properties of the solids are explained by showing the solid objects that are frequently used in daily life, it can be possible for prospective teachers to understand the information about the solids better and this information to be permanent.

Using models when talking about the crystal structures of solids and showing how crystal structures form using animations can facilitate understanding of three-dimensional structures of solids.

In the implementation of problem-based learning, carefully determining the problem situations to be used, adjusting the size of the group, and forming homogeneous groups significantly affect the success of this method.

Time is very important in the use of the problem-based learning approach. In the application of this method, the teaching period should be carefully adjusted.

Conducting such studies on other science topics will facilitate the implementation of this method in the future, reveal its shortcomings and will enable prospective teachers to learn the subjects in a more meaningful way by associating them with daily life.

\section{References}

Açıkyıldız, M. (2004). Probleme Dayalı Öğrenmenin Fizikokimya Laboratuarı Deneylerinde Etkililiğinin İncelenmesi. Yayınlanmamış Yüksek Lisans Tezi, Atatürk Üniversitesi, Erzurum.

Akpınar, E., \& Ergin, Ö. (2005). Probleme Dayalı Öğrenme Yaklaşımına Yönelik Öğrenci Görüşleri. İnönü Üniversitesi Ë̆itim Fakültesi Dergisi, 6, 9.

Barrows, H. S., \& Tamb, R. M. (1980). Problem Based Learning: An Approach to Medical Education. New York: Springer.

Bodner, G. M. (1986). Constructivism: A theory of Knowledge. Journal of Chemical Education, 63, 873-878. https://doi.org/10.1021/ed063p873

Bodner, G. M. (2001). Why Lecture Demonstrations Are 'Exocharmic' for both Students and Their Instructors. University Chemistry Education, 5, 31-36.

Bonsting, J. J. (1992). The quality revolution in education. Educational Leadership, 50(3), 4-9.

Cancilla, D. A. (2001). Integration of Environmental Analytical Chemistry with Environmental Law: The Development of a Problem-Based Laboratory. Journal of Chemical Education, 78, 1652-1659. https://doi.org/10.1021/ed078p1652

Canpolat, N. (2002). Kavramsal Değişim Yaklaşımının Kimyasal Denge Kavramlarının Anlaşılmasında Etkinliğinin Incelenmesi. Yayınlanmamış Doktora Tezi, Atatürk Üniversitesi, Fen Bilimleri Enstitüsü, Erzurum.

Chang, C. (2001). Construction and evaluation of a web-based learning portfolio system: an electronic assessment tool. Innovations in Education and Teaching International, 38, 144-155. https://doi.org/10.1080/13558000010030194

Dicle, O. (2001). Değişen Tıp Eğitimi ve Probleme Dayalı Öğrenme Yönteminin Temel Felsefesi. Tlp Fakültesi Dergisi, 1(1). 
Freedman, M. P. (1997). Relationship among Laboratory Instruction, Attitude toward Science and Achievement in Science Knowledge. Journal of Research in Science Teaching. 34(4), 343-357. https://doi.org/10.1002/(SICI)1098-2736(199704)34:4<343::AID-TEA5>3.0.CO;2-R

Geban, Ö. (1990). İki Farklı Öğretim Yönteminin Lise Seviyesindeki Öğrencilerin Kimya Başarılarına, Bilimsel Işslem Becerilerine ve Kimyaya Karşı Olan Tutumlarına Etkisi. Yayınlanmamış Doktora Tezi, Orta Doğu Teknik Üniversitesi, Fen Bilimleri Eğitimi Bölümü, Ankara.

Geban, Ö., Askar, P., \& Özkan, I. (1992). Effects of computer simulations and problem solving approaches on high school students. Journal of Educational Research, 86, 5-10. https://doi.org/10.1080/00220671.1992.9941821

Geban, Ö., Ertepınar, H., Yılmaz, G., Altın, A., \& Şahbaz, F. (1994). Bilgisayar destekli eğitimin öğrencilerin fen bilgisi başarılarına ve fen bilgisi ilgilerine etkisi. I. Ulusal Fen Bilimleri Eğitimi Sempozyumu: Bildiri Özetleri Kitabı, (1-2), 9. Eylül Üniversitesi, İzmir.

Gülçiçek, G., \& Güneş, B. (2004). Fen Öğretiminde Kavramların Somutlaştırılması: Modelleme Stratejisi. Bilgisayar simülasyonlart ve Analojiler. Ĕgitim ve Bilim, 29, 36-48.

Harrison, A. G., \& Treagust, D. F. (2001). Conceptual Change Using Multiple Interpretive Perspectives: Two Case Studies in Secondary School Chemistry. Instructional Science, 29, 45-85. https://doi.org/10.1023/A:1026456101444

Kaptan, S. (1998). Araştırma ve İstatistik Teknikleri. Tekışık Web Ofset Tesisleri, 11. Baskı, Ankara.

Karasar, N. (1998). Bilimsel Araştırma Yöntemi. Nobel Yayın Dă̆ıtım, 8, 97, Ankara.

Markow, P. G., \& Lonning, R. A. (1998). Usefulness of Concept Maps in College Chemistry Laboratories: Students' Perceptions and Effects on Achievement. Journal of Research Science Teaching, 35, 1015-1029. https://doi.org/10.1002/(SICI)1098-2736(199811)35:9<1015::AID-TEA4>3.0.CO;2-G

McMillan, J. H., \& Schumacher, S. (2001). Research in Education. Addision Wesley Longman: USA.

Miller, S. K. (2003). A Comparison of Student Outcomes Following Problem-Based Learning Instruction Versus Traditional Lecture Learning in a Graduate Course. Journal of American Academy of Nurse Practitioners, 15, 550-556. https://doi.org/10.1111/j.1745-7599.2003.tb00347.x

Milner-Bolotin, M., \& Svinicki, M. D. (2000). Teaching physics of everyday life: Project-based instruction and collaborative work in undergraduate physics course for nonscience majors. Journal of Scholarship in Teaching and Learning, 1(1), 25-40.

Özden, Y. (2005). Öğrenme ve Öğretme. Pegem A Yayıncılık 7. Baskı, Ankara.

Padilla, J. M., \& Okey, J. R. (1984). The Effects of Instruction on Integrated Science Process Skill Achievement. Journal of Research in Science Teaching, 21(3), 277-287. https://doi.org/10.1002/tea.3660210305

Pınarbaşı, T. (2002). Çözünürlükle ilgili kavramların anlaşılmasında kavramsal değişim yaklaşımının etkinliğinin incelenmesi. Yayınlanmamış Doktora Tezi, Atatürk Üniversitesi, Fen Bilimleri Enstitüsü, Erzurum.

Polanco, R., Patricia, C., \& Francisco, D. (2004). Effects of a problem-based learning program on engineering students' academic achievements in a Mexican university 1. Innovations in Education \& Teaching International, 41, 145-155. https://doi.org/10.1080/1470329042000208675

Rhem, J. (1998). Problem-Based-Learning: An Introduction. The National Teaching \& Learning Forum, 8(1), 1-4.

Selco, J. I., Roberts, J. L., \& Wacks, D. B. (2003). The Analysis of Seawater: A Laboratory-Centered Learning Project in General Chemistry. Journal of Chemical Education, 80, 54-57. https://doi.org/10.1021/ed080p54

Stepien, W., J., Gallagher, S. A., \& Workman, D. (1993). Problem-Based Learning for traditional and interdisciplinary classrooms. Journal for the Education of the Gifted, 16(4), 338-345. https://doi.org/10.1177/016235329301600402

Sundblad, G., Sigrell B., John L. K., \& Lindkvist, C. (2002). Students' evaluation of a learning method: a comparison between problem-based learning and more traditional methods in a specialist university training programme in psychotherapy. Taylor \& Francis, 24(3), 268-272.

Svinicki, M. D. (2007). Moving Beyond "It worked": The Ongoing Evolution of Research on Problem-Based Learning in Medical Education. Educ Psychol Rev., 19, 49-61. https://doi.org/10.1007/s10648-006-9040-1

Şenocak, E. (2005). Probleme Dayalı Öğrenme Yaklaşımının Maddenin Gaz Hali Konusunun Öğretimine Etkisi 
Üzerine Bir Araştırma. Yayınlanmamış Doktora Tezi, Atatürk Üniversitesi, Fen Bilimleri Enstitüsü, Erzurum.

Tepe, D. (1999). Öğrencilerin Fen Derslerine Karşı Tutumları ile Başarıları Arasındaki İlişki. İstanbul: Marmara Üniversitesi Fen Bilimleri Enstitüsü, Yayınlanmamış Yüksek Lisans Tezi.

Tobin, K. (1986). Student task: Involvement and achievement in process-oriented science activities. Science Education, 70, 61-72. https://doi.org/10.1002/sce.3730700108

Walker, J. T. (2001). The Effect of a Problem Based Learning Curriculum on Students' Perceptions about Self Directed Learning (Unpublished Phd Thesis). The University of Mississippi.

Weiss, R. E. (2003). Designing problems to promote higher-order thinking. New Directions for Teaching and Learning, 95, 25-31. https://doi.org/10.1002/tl.109

Yeung, E., Au-Yeung, S., Chiu, T., Mok, N., \& Lai, P. (2003). Problem Design in Problem-Based Learning: Evaluating Students' Learning and Self-directed Learning Practice. Innovations in Education and Teaching International, 40, 237-244. https://doi.org/10.1080/1470329032000103762

Ying, Y. (2003). Using Problem-Based Teaching and Problem-Based Learning to Improve the Teaching of Electrochemistry. The China Papers, July, 42-47. 